\title{
Effects of Flooding and Temperature on Aedes albifasciatus Development Time and Larval Density in Two Rain Pools at Buenos Aires University City
}

\author{
M Soledad Fontanarrosa, M Cristina Marinone, Sylvia Fischer, \\ Pablo W Orellano, Nicolás Schweigmann
}

\begin{abstract}
Departamento de Ciencias Biológicas, Facultad de Ciencias Exactas y Naturales, Universidad de Buenos Aires, Pabellón II, Ciudad Universitaria, C1428EHA Buenos Aires, Argentina
\end{abstract}

Aedes albifasciatus is a floodwater mosquito that breeds in temporary waters. This semi-domestic species, widely distributed in Argentina, is a competent vector of the western equine encephalitis. The present study was carried out in two rain pools of the city of Buenos Aires, from April 1998 through March 1999. Samples were taken twice a week during the cold season and daily during the warmer months, starting from October. Immature mosquitoes were collected with a dipper, being the number of dippers proportional to the flooded area. The estimated rainfall thresholds to initiate cohorts of Ae. albifasciatus were: $16-17 \mathrm{~mm}$ in the fall-winter period, $25 \mathrm{~mm}$ in the spring, and $30 \mathrm{~mm}$ in the summer. The development time of the different cohorts and the mean air temperature of their respective periods were estimated in all seasons, ranging from six days $\left(\right.$ at $\left.24^{\circ} \mathrm{C}\right)$ to 32 days $\left(\right.$ at $\left.13^{\circ} \mathrm{C}\right)$. The equation that best expresses the relationship between development time and mean air temperature is $d t=$ $166,27 . e^{-0,1435 . T}\left(R^{2}=0,92\right)$. Significantly shorter development times were recorded for larvae of the first three stages as compared to the fourth larval stage and pupae.

Key words: Aedes albifasciatus - development time - floodwater mosquitoes - rain pools - temporary habitats Argentina

Aedes (Ochlerotatus) albifasciatus (Macquart) is a Neotropical mosquito widely distributed in Argentina (Darsie 1985, Mitchell \& Darsie 1985). Together with Culex quinquefasciatus, this species reaches the southern limit of the Argentine Patagonia, where it has been recorded up to Tierra del Fuego (Bachmann \& Bejarano 1960, Prosen et al. 1960).

This semi-domestic species that insistently attacks men, domestic mammals, and birds (Del Ponte \& Blaksley 1947, Ludueña Almeida \& Gorla 1995 ) is considered one of the most bothersome mosquitoes of the region (Prosen et al. 1960). Ae. albifasciatus is a competent vector of western equine encephalitis (WEE) under laboratory conditions (Avilés et al. 1990), and the virus has also been isolated from wild specimens during the 1982-

This research was supported by a covenant endorsed by the Government of the City of Buenos Aires and the Faculty of Exact and Natural Sciences of the University of Buenos Aires.

Corresponding author. Fax: 0054-11-4576-3384.

E-mail: mosquito@bg.fcen.uba.ar

Received 8 February 2000

Accepted 3 July 2000
1983 Argentine epidemic outbreak (Mitchel et al. 1987). Because of its distribution, abundance, host preference, vectorial competence, and documented infection in nature, Ae. albifasciatus is the primary mosquito species to be incriminated as WEE virus vector in South America (Sabattini et al. 1998).

This mosquito breeds in shallow temporary waters (Prosen et al. 1960) of variable size, either natural or artificial, with or without vegetation (Ludueña Almeida \& Gorla 1995), mainly localized in plains (Forattini 1965). Females lay their eggs in the wet soil surrounding the pools. Once the embryonic development has been completed (four days in a moist environment), the eggs may either enter a period of diapause (withstanding four to six months of drought) (Ludueña Almeida \& Gorla 1995) or hatch producing first stage larvae, when flooding and temperature at the breeding sites are suitable to this species (Maciá et al. 1995).

The fluctuations in the abundance of the larvae of the genus Aedes are basically linked to the flood regime of the breeding sites (Maciá et al. 1995), which, in turn, depend both on flooded area and water permanence during the time required to complete the preimaginal development (Gleiser \& Gorla 1997).

The extension of the flooded area is directly related to rainfall volume and inversely related to 
the time elapsed since the last rain event, owing to evaporation and/or infiltration (Gleiser \& Gorla 1997). Since these phenomena depend on insolation intensity (reflected by air temperature), there are seasonal differences in the degree and persistence of flooding produced by similar rainfall volumes (Fischer et al. manusc. in prep.). Thus, the organisms living in these habitats are dependent on atmospheric temperature.

The present study analyzes the effects of rainfall dynamics and air temperature on the appearance and development of new cohorts of Ae. albifasciatus, under field conditions. We propose the function that best represents the relationship between preimaginal development time and air temperature, also estimating the development time of each stage. The relationship between the presence and the abundance of immature stages with some environmental factors is also analyzed.

\section{MATERIALS AND METHODS}

The study was carried out in two pools of the sports playground of the University City of Buenos Aires. This campus is situated in the northeastern zone of the Province of Buenos Aires ( $34^{\circ} 55^{\prime} \mathrm{S}$, $58^{\circ} \mathrm{W}$ ) limiting with De la Plata River to the east. Both water bodies were located on clayey soils, one of them exposed to the sunlight and the other under the shadow of a small pine-tree stand. These pools were subjected to an intermediate level of perturbation, especially during the weekends, owing to the recreational use of the land.

The local meteorological information (daily precipitation and maximum and minimum temperatures) was obtained from the station at the University City (Department of Atmosphere Sciences, Faculty of Exact and Natural Sciences, University of Buenos Aires). Missing data were estimated from the records of the meteorological station at Jorge Newbery Airport (National Meteorological Service, Argentine Air Force), located approximately at $3.5 \mathrm{~km}$ from the study site. Since water temperature is usually unavailable, we consider the air temperature to represent it adequately.

The pools were monitored systematically from April 1998 through March 1999, when the piping works carried out by the Government of the City of Buenos Aires prevented subsequent flooding of this area. Studies started two days after the first rain $(31.2 \mathrm{~mm})$ recorded during the period, following a fortnight without rainfalls. Samples were taken twice a week during the cold season and daily during the warmer months, starting from October. Maximum depth, length, and width of both pools were measured on each sampling occasion. The flooded area was estimated from field sketches taking into account the maximum dimensions of each pool. The flood level at any particular date was quantified by considering an arbitrary scale with the maximum flooded area as the reference level: 4 (1140-1520 $\mathrm{m}^{2}$ or $100 \%$ flooded area), 3 (760$1139 \mathrm{~m}^{2}$ or $\left.75 \%\right), 2$ (380-759 $\mathrm{m}^{2}$ or $\left.50 \%\right), 1$ (up to $379 \mathrm{~m}^{2}$ or $25 \%$ ), and 0 (dry pool).

Quantitative samples of immature mosquitoes were collected with $80 \mathrm{ml}$ plastic dippers, taking a volume proportional to the flooded area (5 to 130 dippers). Samples were fixed in situ in $70 \%$ ethanol. Mosquitoes were discriminated by stage, counted and identified to specific level (Darsie 1985) under stereoscopic microscope.

The day following each rain event was considered as the starting day of the first larval stage (day 1) of a new cohort (Ludueña Almeida \& Gorla 1995). A stage was considered to be present if its abundance represented at least $10 \%$ of the sample at any given date. The end of the cycle was assigned to the day when the number of captured pupae was less than $10 \%$ respect to the mean of the captures during the previous dates.

The development times of the different cohorts and stages were estimated for mean air temperatures calculated from daily mean temperatures. The times estimated from field data were adjusted to an exponential function. The development times of the different stages were compared by means of ANCOVA (Sokal \& Rohlf 1981), taking temperature as a covariable. Since development time cannot be assumed to be a normally distributed variable (Rueda et al. 1990), data were log transformed $(\log \mathrm{x})$. The assumptions of homocedacy and parallelism were verified, and the significance of the regressions calculated. The means of the development times of the different stages were compared by means of a posteriori contrasts using Tukey's method (Sokal \& Rohlf 1981).

\section{RESULTS}

The pools contained water most of the time of the study period, remaining dry a total of three months divided into nine to ten drought events. The maximum surface areas estimated reached 1,010 $\mathrm{m}^{2}$ for the pool exposed to the sun and $1,517 \mathrm{~m}^{2}$ for the pool in the shadow, whereas the greatest depths recorded were 27 and $32 \mathrm{~cm}$ respectively. Although water level fluctuations showed similar dynamics in both habitats (Fig. 1), the pool located in the shadow attained a greater level of flooding than the one exposed to the sun. The noticeable variations in the surface area of the pool in the shadow recorded at beginning of March 1999 obey to the start of the piping works.

In both pools the minimum flooding required by a cohort of Ae. albifasciatus to complete its development cycle was of the second level (Fig. 

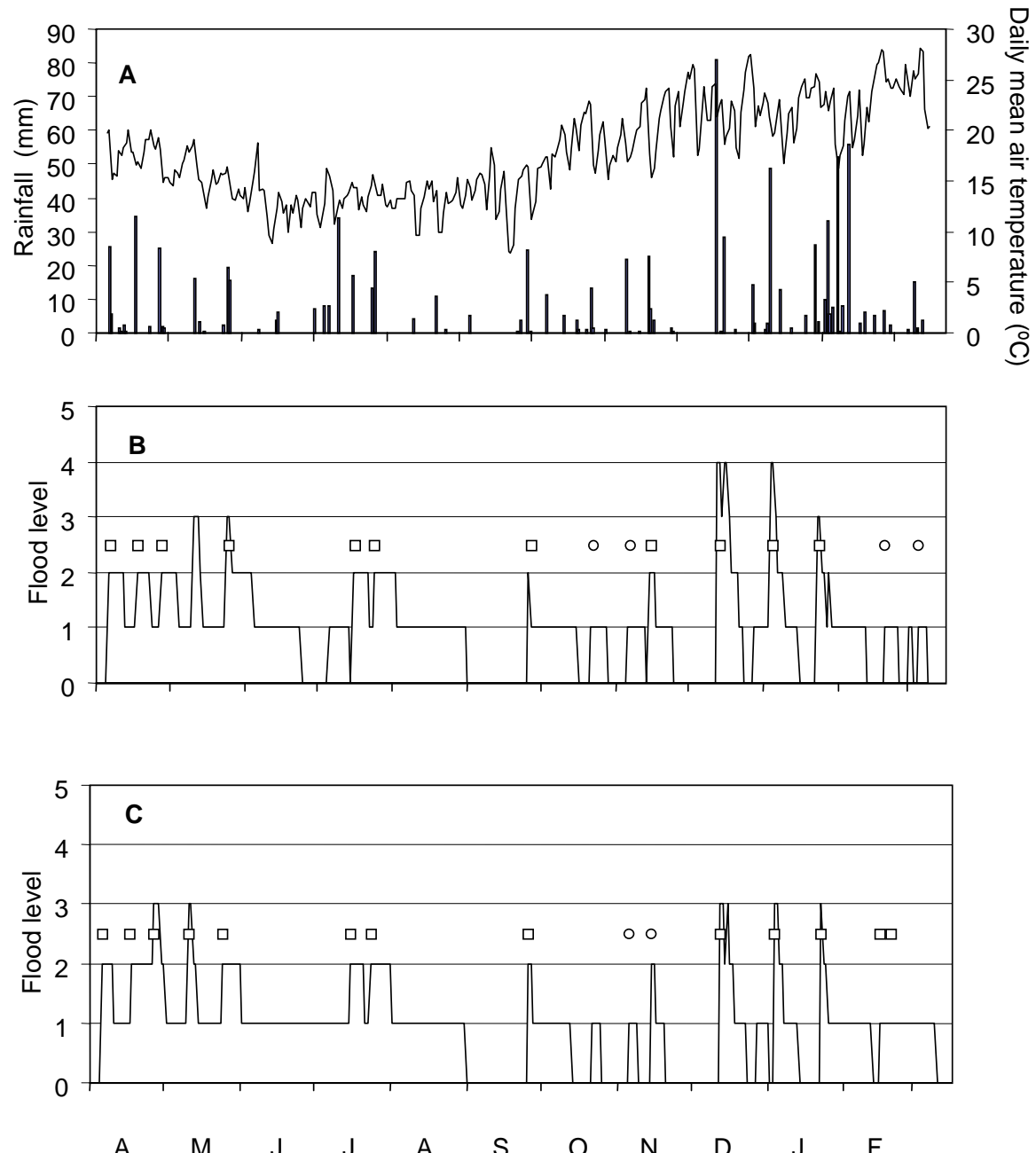

Fig. 1 - A: mean air temperature and accumulated rainfall during the study period; B: variation in the surface area of the pool located in the shadow; C: variation in the surface area of the pool exposed to the sun $(\square$ : start of successful cohorts, $\bigcirc$ : start of failed cohorts).

1). Both in the fall and in the winter, rainfall volumes of 16 or $17 \mathrm{~mm}$ were sufficient to reach such flooding level. On the other hand, the rainfall volumes required to attain the same flooding level in the spring and in the summer, were 25 and $30 \mathrm{~mm}$ respectively.

During the fall-winter period eight rainfall events exceeded the estimated threshold. New cohorts of Ae. albifasciatus were detected in seven opportunities out of these eight events, but in the remaining case the flooding attained only the first category of our scale. From the four rain events exceeding $25 \mathrm{~mm}$ recorded in the spring, larval eclosion could not be detected on a single occasion, when it rained on a very damp soil. In the same way, of the five rain events greater than or equal to $30 \mathrm{~mm}$ recorded in the summer, new co- horts started when the soil had dried completely before the rain.

In the study zone, the immature stages of $A e$. albifasciatus were found year round, presenting seasonal variations in their relative abundance, with peak values in the spring (Fig. 2). In most cases, larval production was higher in the pool located in the shadow.

The duration of the development cycle showed a wide range of variation, from a minimum of six days (at $24^{\circ} \mathrm{C}$ ) to a maximum of 32 days $\left(\right.$ at $13^{\circ} \mathrm{C}$ ) (Fig. 3). The comparison of the estimates of the development times between pools did not show significant differences $(\mathrm{p}<0.05)$.

The function that best expresses the relationship between the development time (dt) of all the studied cohorts of Ae. albifasciatus as a whole 

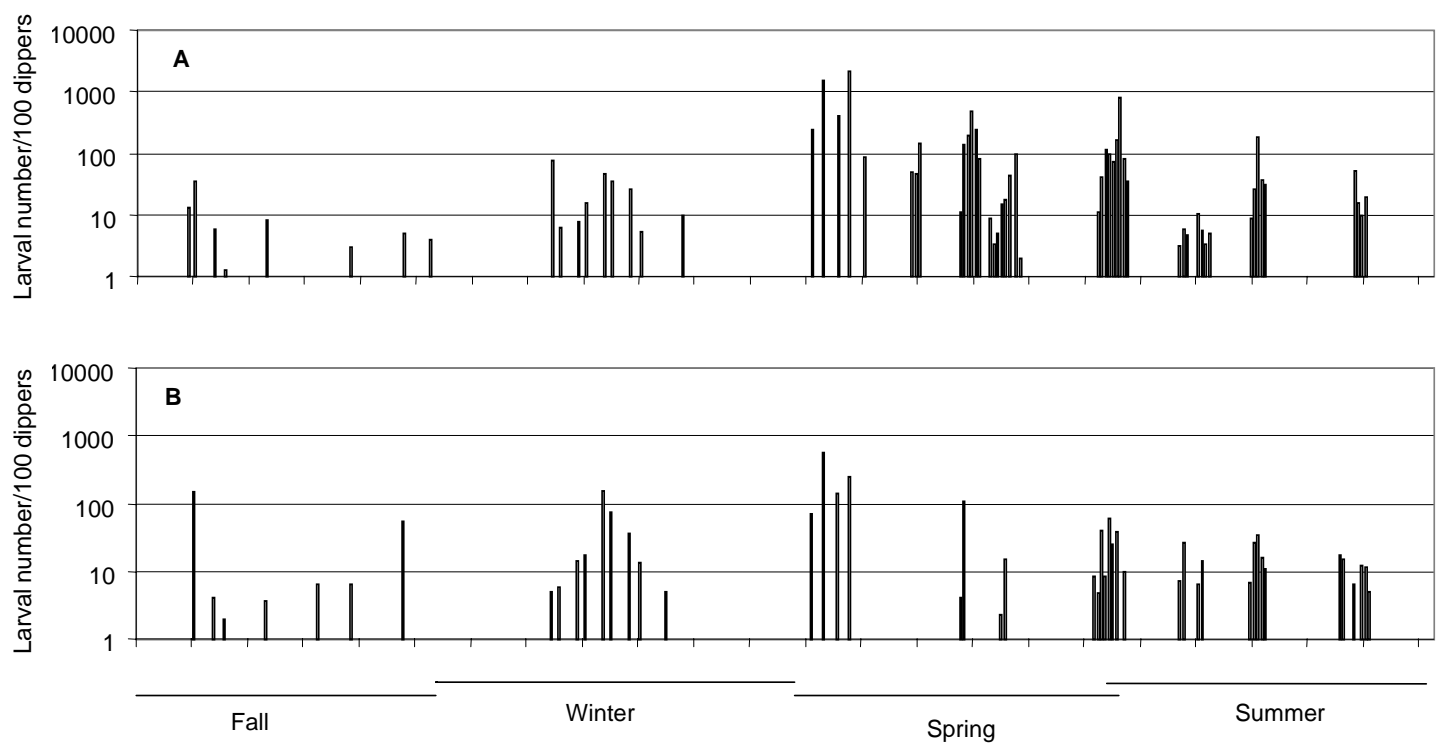

Fig. 2 - A: variation in the abundance of Aedes albifasciatus during the study period in the pool located in the shadow; B: variation in the abundance of Ae. albifasciatus during the study period in the pool exposed to the sun.

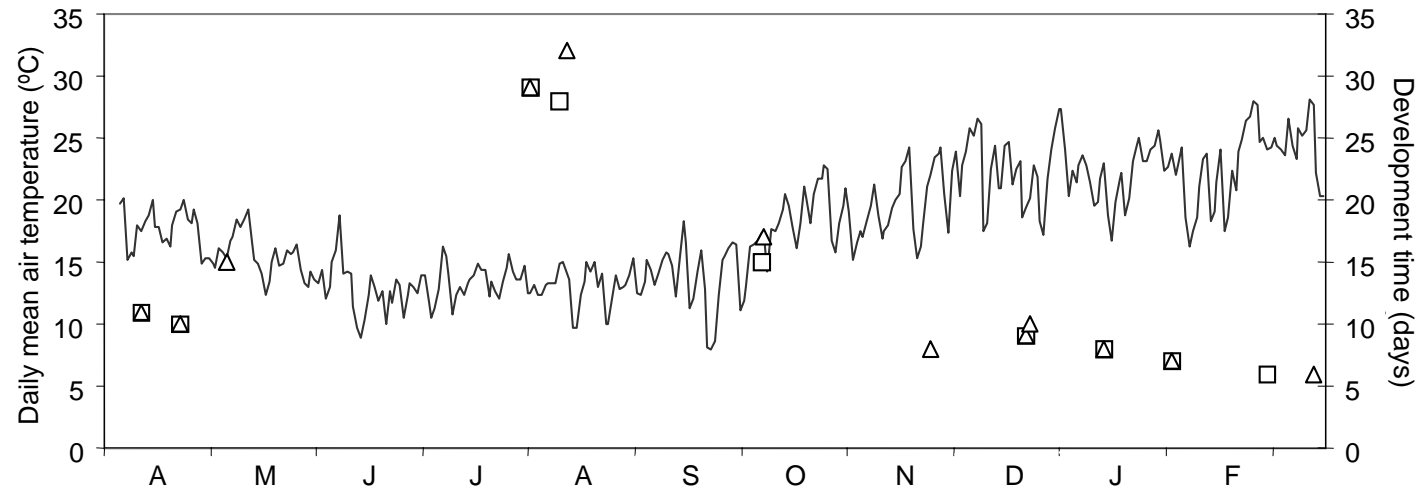

Fig. 3: development time of Aedes albifasciatus in the study pools

(measured in days) respect to air temperature (T) (measured in Celsius degrees) is: $\mathrm{dt}=166.27$. $\mathrm{e}^{-0,1435 . \mathrm{T}}\left(\mathrm{R}^{2}=0.92\right)$ (Fig. 4).

Significant differences $(p<0.01)$ were found among the development times of the different stages. The results of the contrasts are presented in the Table. The larvae of the first, second and third stages develop significantly faster $(\mathrm{p}<0.01)$ than the fourth stage larvae and pupae. The regression lines for each stage are shown in Fig. 5.

\section{DISCUSSION}

The combined effects of rain and temperature influence the quantity and permanence of temporary water bodies. Wiggins et al. (1980) consider

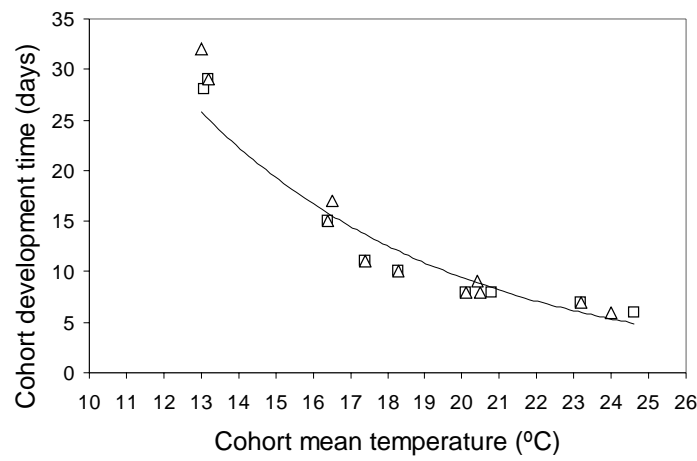

Fig. 4: development time of Aedes albifasciatus as a function of mean air temperature ( $\square$ : pool exposed to the sun; $\triangle$ : pool in the shadow) 


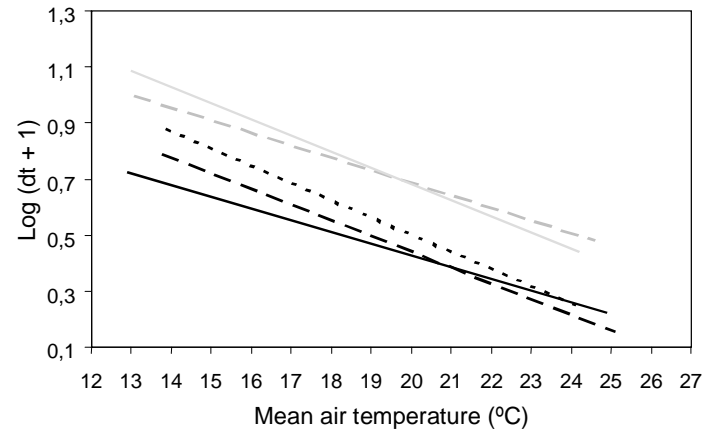

Fig. 5: regression lines of the development time of the different immature stages of Aedes albifasciatus as a function of mean air temperature; larvae $1\left({ }^{\prime}\right)$, larvae $2(-\quad$ - $)$, larvae $3(\cdot \cdot \cdot)$, larvae $4(-)$, and pupae $\left(--{ }_{-}\right)$

the term temporary pool to be more appropriate for the small, shallow and highly ephemeral waters. In agreement with these authors, and considering that our study pools persisted from one week to three months, they can be included in this habitat category. On the other hand, since the filling frequency of these habitats was practically unpredictable, or they contain water in an unrecognizably cyclical pattern, these pools were also categorized as episodic (Williams 1997). The estimated rainfall thresholds, varied along the year in relation to air temperature, which in turn affects the evaporation velocity and water permanence in the pools. During the fall-winter period, less frequent and less abundant rainfalls combined with low temperatures, produced the water-saturation of the soils, thus maintaining a relatively stable flooding level (Fig. 1). The association of these factors allowed the development of broods of Ae. albifasciatus during the cold season. Although the cohorts produced during this season were less abundant as compared to other periods, they kept the population at a basic level of activity even in the coldest months. In agreement with our observations, immature stages of this mosquito were also captured during the fall-winter period in the Province of Córdoba (Almirón \& Brewer 1994). During the warm season, in spite of the greater volumes of rain, which doubled the winter standards, the high temperatures remarkably reduced the permanence of the pools by facilitating a fast drying of the soil.

The presence of this species is basically determined by fluctuations of the flooding levels (Fig. 1). In coincidence with published data (Ludueña Almeida \& Gorla 1995, Maciá et al. 1995), we observed that the highest abundances of immature mosquitoes and subsequent peaks of the adult population, occurred after periods of drought (Fig. 2 ). This fact may be explained by the joint eclosion of great quantities of eggs accumulated during droughts, though this assumption deserves future research.

The range of temperatures recorded in the city of Buenos Aires seems to be favorable to Ae. albifasciatus. Temperature is the main regulating factor of the velocity of preimaginal development in this species (Figs 3,4). The longest development times (28-32 days) were recorded during the winter, then diminishing at increasing temperatures, to reach 5 to 17 days during the warmer months. Contradicting our results, and in spite of the close climatic similarity, studies carried out in the neighboring locality of Punta Lara (at $52 \mathrm{~km}$ from Buenos Aires) conclude that the extreme temperatures of winter and summer may preclude the eclosion of the eggs of this species (Maciá et al. 1995).

According to our results, the spring can be considered a critical period for some cohorts whose development was interrupted when the pools dried out. Our data suggest that development speed would not be modified by the rate of pool disappearance (Table). However, further research is required to support this assertion. Therefore, the success of a brood of Ae. albifasciatus is related to a combination of two main factors: the presence of water and the temperatures of the period.

Given the synchronization in the emergence of the adults of Ae. albifasciatus after rain events, the planning of control programs not only requires an accurate estimation of emergence times but also a good knowledge on the location of breeding sites. The piping works carried out in the study area are a convincing example of an effective and feasible control action that prevented subsequent flooding, thus eliminating two important mosquito breeding sites.

The identification of the rainfall threshold levels that originate floodings lasting enough time to complete the development cycle of Ae. albifasciatus is a good starting point to plan control programs in the urban parks. Additionally, the estimation of the duration of the preimaginal cycle and the development time of each stage under field conditions are useful data to build and/or validate more complex models of mosquito development.

\section{ACKNOWLEDGEMENTS}

To Mr Santiago Zelenay and Mr Federico Weyland for their collaboration with the field and laboratory work. To Dr Arnaldo Maciá for his critical revision of the manuscript and to Dr Javier Calcagno for his statistical advice. 
TABLE

Development time of the different immature stages of Aedes albifasciatus as a function of mean air temperature. The means of the development times were adjusted to a mean temperature of $19.4^{\circ} \mathrm{C}$

\begin{tabular}{|c|c|c|c|c|c|c|c|c|c|c|}
\hline \multirow{2}{*}{$\begin{array}{l}\text { Stage } \\
\text { Hatching } \\
\text { date }\end{array}$} & \multicolumn{2}{|c|}{ Larvae 1} & \multicolumn{2}{|c|}{ Larvae 2} & \multicolumn{2}{|c|}{ Larvae 3} & \multicolumn{2}{|c|}{ Larvae 4} & \multicolumn{2}{|c|}{ Pupae } \\
\hline & $\begin{array}{l}\text { Development } \\
\text { time } \\
\text { (days) }\end{array}$ & $\begin{array}{c}\text { Mean air } \\
\text { temperature } \\
\left({ }^{\circ} \mathrm{C}\right)\end{array}$ & $\begin{array}{c}\text { Development } \\
\text { time } \\
\text { (days) }\end{array}$ & $\begin{array}{c}\text { Mean air } \\
\text { temperature } \\
\left({ }^{\circ} \mathrm{C}\right)\end{array}$ & $\begin{array}{l}\text { Development } \\
\text { time } \\
\text { (days) }\end{array}$ & $\begin{array}{c}\text { Mean air } \\
\text { temperature } \\
\left({ }^{\circ} \mathrm{C}\right)\end{array}$ & $\begin{array}{c}\text { Development } \\
\text { time } \\
\text { (days) }\end{array}$ & $\begin{array}{c}\text { Mean air } \\
\text { temperature } \\
\left({ }^{\circ} \mathrm{C}\right)\end{array}$ & $\begin{array}{c}\text { Development } \\
\text { time } \\
\text { (days) }\end{array}$ & $\begin{array}{r}\text { Mean air } \\
\text { temperature } \\
\left({ }^{\circ} \mathrm{C}\right)\end{array}$ \\
\hline 17-Jul & $\begin{array}{l}6 \\
5\end{array}$ & $\begin{array}{l}13.0 \\
12.9\end{array}$ & $\begin{array}{l}6 \\
6\end{array}$ & $\begin{array}{l}13.8 \\
13.8\end{array}$ & $\begin{array}{l}7 \\
8\end{array}$ & $\begin{array}{l}14.1 \\
13.9\end{array}$ & $\begin{array}{l}10 \\
10\end{array}$ & $\begin{array}{l}13.1 \\
13.1\end{array}$ & $\begin{array}{l}12 \\
12\end{array}$ & $\begin{array}{l}13.0 \\
13.0\end{array}$ \\
\hline 27-Sep & $\begin{array}{l}5 \\
4\end{array}$ & $\begin{array}{l}13.7 \\
13.1\end{array}$ & $\begin{array}{l}5 \\
3\end{array}$ & $\begin{array}{l}16.8 \\
16.4\end{array}$ & $\begin{array}{l}6 \\
4\end{array}$ & $\begin{array}{l}16.6 \\
16.4\end{array}$ & $\begin{array}{l}7 \\
4\end{array}$ & $\begin{array}{l}18.1 \\
16.8\end{array}$ & $\begin{array}{l}6 \\
3\end{array}$ & $\begin{array}{l}18.5 \\
19.7\end{array}$ \\
\hline $23-\mathrm{Oct}$ & 3 & 16.8 & 3 & 19.5 & 2 & 19.9 & dry pool & & dry pool & \\
\hline 07-Nov & $\begin{array}{l}2 \\
2\end{array}$ & $\begin{array}{l}17.7 \\
17.7\end{array}$ & $\begin{array}{l}1 \\
1\end{array}$ & $\begin{array}{l}19.4 \\
19.4\end{array}$ & $\begin{array}{c}2 \\
\text { dry pool }\end{array}$ & 20.2 & $\begin{array}{c}3 \\
\text { dry pool }\end{array}$ & 22.1 & $\begin{array}{l}\text { dry pool } \\
\text { dry pool }\end{array}$ & \\
\hline 16-Nov & $\begin{array}{l}3 \\
2\end{array}$ & $\begin{array}{l}16.5 \\
15.8\end{array}$ & $\begin{array}{l}2 \\
2\end{array}$ & $\begin{array}{l}19.5 \\
19.5\end{array}$ & $\begin{array}{l}3 \\
1\end{array}$ & $\begin{array}{l}22.2 \\
22.0\end{array}$ & $\begin{array}{c}4 \\
\text { dry pool }\end{array}$ & 23.4 & $\begin{array}{c}2 \\
\text { dry pool }\end{array}$ & 24.0 \\
\hline 14-Dec & $\begin{array}{l}1 \\
1\end{array}$ & $\begin{array}{l}22.5 \\
22.5\end{array}$ & $\begin{array}{l}2 \\
1\end{array}$ & $\begin{array}{l}20.8 \\
23.1\end{array}$ & $\begin{array}{l}2 \\
1\end{array}$ & $\begin{array}{l}19.0 \\
18.6\end{array}$ & $\begin{array}{l}3 \\
3\end{array}$ & $\begin{array}{l}20.8 \\
20.8\end{array}$ & $\begin{array}{l}4 \\
3\end{array}$ & $\begin{array}{l}20.0 \\
21.0\end{array}$ \\
\hline 05-Jan & $\begin{array}{l}1 \\
1\end{array}$ & $\begin{array}{l}19.5 \\
19.5\end{array}$ & $\begin{array}{l}1 \\
1\end{array}$ & $\begin{array}{l}19.8 \\
19.8\end{array}$ & $\begin{array}{l}2 \\
1\end{array}$ & $\begin{array}{l}20.8 \\
21.8\end{array}$ & $\begin{array}{l}4 \\
3\end{array}$ & $\begin{array}{l}19.6 \\
19.5\end{array}$ & $\begin{array}{l}4 \\
3\end{array}$ & $\begin{array}{l}19.2 \\
19.4\end{array}$ \\
\hline 24-Jan & $\begin{array}{l}1 \\
1\end{array}$ & $\begin{array}{l}24.9 \\
24.9\end{array}$ & $\begin{array}{l}1 \\
1\end{array}$ & $\begin{array}{l}22.3 \\
22.3\end{array}$ & $\begin{array}{l}2 \\
1\end{array}$ & $\begin{array}{l}22.2 \\
22.6\end{array}$ & $\begin{array}{l}3 \\
2\end{array}$ & $\begin{array}{l}22.9 \\
22.9\end{array}$ & $\begin{array}{l}2 \\
3\end{array}$ & $\begin{array}{l}22.5 \\
23.0\end{array}$ \\
\hline 21-Feb & 1 & 24.8 & 1 & 25.1 & 1 & 24.1 & 2 & 24.6 & 2 & 24.2 \\
\hline Adjusted 1 & $2.8 \mathrm{a}$ & & $3 a$ & & $3.4 \mathrm{a}$ & & $5.2 \mathrm{~b}$ & & $5.1 \mathrm{~b}$ & \\
\hline
\end{tabular}

Adjusted means for the first, second and third larval stages (followed by the letter a) were significantly different ( $\mathrm{p}<0.01$; Tukey's test) from the fourth stage larvae and pupae (followed by the letter b). 


\section{REFERENCES}

Almirón WR, Brewer ME 1994. Immature stages of mosquitoes (Diptera: Culicidae) collected during the autumn-winter period in Córdoba Province, Argentina. Mem Inst Oswaldo Cruz 89: 625-628.

Avilés G, Bianchi TI, Mitchell CJ 1990. Peroral susceptibility of Aedes albifasciatus and Culex pipiens complex mosquitoes (Diptera: Culicidae) from Argentina to Western Equine Encephalitis Virus. Rev Saú Púb 24: 265-269.

Bachmann AO, Bejarano JER 1960. Dispersión de mosquitos en la Patagonia (Dipt. Culicidae - Culicinae). Neotropica 6: 70-71.

Darsie Jr RF 1985. Mosquitoes of Argentina. Part I. Keys for identification of adult females and fourth stage larvae in English and Spanish (Diptera, Culicidae). Mosq Syst 17: 153-253.

Del Ponte E, Blaksley JC 1947. Importancia sanitaria de los Culicidae de la ciudad de Buenos Aires. $L a$ Prensa Médica Argentina 34: 821-824.

Forattini OP 1965. Entomología Médica. 2. Culicini: Culex, Aedes e Psorophora, Univ. São Paulo, 506 pp.

Gleiser RM, Gorla DE 1997. Abundancia de Aedes (Ochlerotatus) albifasciatus (Diptera: Culicidae) en el sur de la laguna Mar Chiquita. Ecología Austral 7: 20-27.

Ludueña Almeida FF, Gorla DE 1995. The biology of Aedes (Ochlerotatus) albifasciatus Macquart, 1838 (Diptera: Culicidae) in Central Argentina. Mem Inst Oswaldo Cruz 90: 463-468.

Maciá A, García JJ, Campos RE 1995. Bionomía de Aedes albifasciatus y Ae. crinifer (Diptera: Culicidae) y sus enemigos naturales en Punta Lara,
Buenos Aires. Neotropica 41: 43-50.

Mitchell CJ, Darsie Jr RF 1985. Mosquitoes of Argentina. Part II. Geographic distribution and bibliography (Diptera, Culicidae). Mosq Syst 17: 279-362.

Mitchell CJ, Monath TP, Sabattini MS, Daffner JF, Cropp CB, Calisher CH, Darsie Jr RF, Jakob WL 1987. Arboviruses isolations from mosquitoes collected during and after the 1982-1983 epizootic of Western Equine Encephalitis in Argentina. Am J Trop Med Hyg 36: 107-113.

Prosen AF, Martínez A, Carcavallo RU 1960. La familia Culicidae (Diptera) en la ribera fluvial de provincia de Buenos Aires. An Inst Med Regional 5: 101-113.

Rueda LM, Patel KJ, Axtell RC, Stinner RE 1990. Temperature-dependent development and survival rates of Culex quinquefasciatus and Aedes aegypti (Diptera: Culicidae). J Med Entomol 27: 892-898.

Sabattini MS, Avilés G, Monath TO 1998. Historical, epidemiological and ecological aspects of Arboviruses in Argentina: Togaviridae, Alphavirus. In APA Travassos da Rosa, PFC Vasconcelos, JFS Travassos da Rosa (eds), An Overview of Arbovirology in Brazil and Neighbouring Countries, Instituto Evandro Chagas, Belém, p. 135-153.

Sokal RR, Rohlf FJ 1981. Biometry. The Principles and Practice of Statistics in Biological Research, (2nd ed.), WH Freeman and Co., New York, 859 pp.

Wiggins GB, Mackay RJ, Smith IM 1980. Evolutionary and ecological strategies of animals in annual temporary pools. Arch Hydrobiol (Suppl.) 58: 97206.

Williams DD 1997. Temporary ponds and their invertebrate communities. Aquatic Conservation 7: 105117. 